\title{
OPEN Analysis of spatiotemporal changes of agricultural land after the Second World War in Czechia
}

\author{
Vít Zelinka1凶${ }^{1 凶}$ Johana Zacharová ${ }^{2} \&$ Jan Skaloš $^{1}$
}

The term Sudetenland refers to large regions of the former Czechoslovakia that had been dominated by Germans. German population was expelled directly after the Second World War, between 1945 and 1947. Almost three million people left large areas in less than two years. This population change led to a break in the relationship between the people and the landscape. The aim of the study is to compare the trajectories of these changes in agricultural landscapes in lower and higher altitudes, both in depopulated areas and areas with preserved populations. This study included ten sites in the region of Northern Bohemia in Czechia (18,000 ha in total). Five of these sites represent depopulated areas, and the other five areas where populations remained preserved. Changes in the landscape were assessed through a bi-temporal analysis of land use change by using aerial photograph data from time hoirzons of 2018 and 1953. Land use changes from the 1950s to the present are corroborated in the studied depopulated and preserved areas mainly by the trajectory of agricultural land to forest. The results prove that both population displacement and landscape type are important factors that affect landscape changes, especially in agricultural landscapes.

The abandonment or change in the use of less fertile farmlands can be observed throughout Europe. Significant amounts of agricultural land (mainly arable land) have ceased being used for their non-original purposes at higher altitudes since the $1950 \mathrm{~s}^{1}$. An interest in this issue has grown recently ${ }^{2-4}$. Also, thanks to the availability of aerial photographs and geographic information system (GIS) capabilities, many studies are focusing on landscape change and its drivers ${ }^{5-11}$. The depopulation of unhostile mountain regions is a frequent cause of landscape transformation, as the natural conditions such as especially climate and soil quality limit land use. Population growth in urban regions and population decline in rural regions as a result of net migration or natural population change can be observed across Europe ${ }^{12}$. Effect of the depopulation during the twentieth century on landscape structure have been studie in Mediterranean regions, such as in Spain ${ }^{13}$ and Italy ${ }^{14}$. The polarisation of the land uses between either intensification or abandonment directly in recent decades ${ }^{15}$, urban sprawl followed by growth of infrastructures and accompanied by losses of visual values of rural areas ${ }^{16}$ were frequently cited as reasons for landscape changes. And also in the Eastern European case, the so-called socialist industrialisation of agriculture in the post-war period ${ }^{17,18}$. Also, periods of social and economic unrest cause a decrease in the anthropogenic pressure on the landscape. Agricultural land abandonment can be described as the cessation of agricultural activities on arable land, meadows, and pastures with subsequent natural vegetation recovery ${ }^{19}$. This is characterised by a temporary and, in some cases, permanent turning in the development of the secondary landscape structure. That results in succession-scrub encroachment and forest regrowth on agricultural land ${ }^{20,21}$.

Historically, European rural landscapes have been affected by the after-effects of the Second World War, namely the expulsion of German communities from Central and Eastern Europe. There are several studies focused on depopulated areas in Poland, such as the Polish Carpathians ${ }^{22,23}$ or the Polish Sudetes mountains ${ }^{24}$. However, Germans were displaced after 1945 not only from Poland but also from Czechoslovakia, Hungary, Yugoslavia, Romania, and the Baltic countries ${ }^{25}$.

In Czechia, the trend of land abandonment is particularly relevant in the areas from which the German population was expelled directly after the Second World War, between 1945 and 1947. These population fluxes were concentrated in regions that had been dominated by German speaking popullation, called the Sudetenland.

${ }^{1}$ Faculty of Environmental Sciences, Czech University of Life Sciences Prague, Kamycka 129, 16500 Prague, Suchdol, Czech Republic. 'Faculty of Environment, Jan Evangelista Purkyně University in Ústí nad Labem, Pasteurova 3632/15, 40096 Usti nad Labem, Czech Republic. ${ }^{\bowtie}$ email: zelinka@fzp.czu.cz 
The term Sudetenland was originally used for one of the four territories spontaneously proclaimed by the German inhabitants of the border areas of Czechoslovakia after the collapse of the Habsburg Monarchy ${ }^{26}$. This term was later applied to large border areas of Czechoslovakia inhabited mainly by Germans. In the border region of the Sudetenland, a trend of decreasing anthropogenic land use intensity was observed in the study of Bičík and $\mathrm{Kabrda}^{27}$. Vast border regions became suddenly uninhabited, resulting in a significant decrease in arable land and the transition of land cover into forests, meadows, and pastures ${ }^{17}$.

The region affected by this historical process is a unique case for the following reasons. First, the demographic change came very quickly. Almost three million people left large areas in less than two years; this represented a quarter of the population of Czechoslovakia at the time. These vast regions suddenly became uninhabited. The territory of Czechoslovakia formerly occupied by Nazi Germany had an area of nearly $30,000 \mathrm{sq} \mathrm{km}^{28}$, an area comparable to the size of Belgium. Although there was a resettlement process, the population of these regions has never reached pre-war levels. Thus this process led to a decrease in agricultural land and an increase in forest $\operatorname{areas}^{17}$.

This demographic change affected all types of agricultural lands except the most fertile at the lowest altitudes. However, these areas cannot be described as marginal. This population change eliminated traditional methods of farming in various areas and led to a break in the relationship between the people and the landscape where they live ${ }^{17,29}$.

The spatial context of these demographic changes is also interesting. Due to the demarcated areas dominated by the German population ${ }^{28}$, there are often two settlements with different types of demographic developments in a single landscape type ${ }^{30}$ : those which were almost completely depopulated, and on the other hand, those that were only marginally affected by this sudden drop in population.

Thus, this study focuses on the effects of post-war demographic changes on the development of agricultural lands. The aim is to compare the trajectories of these changes in agricultural landscapes, both in depopulated areas and areas with preserved populations, and to detect differences in lowland and highland landscapes. This could help to distinguish precisely the impact of sociological factors and natural conditions on agricultural land abandonment. Despite a slight slowdown in recent years ${ }^{31}$, similar trends of farmland abandonment continue to be widespread land-change processes in Europe. European regions with negative migration balances have higher probabilities of abandonment compared to regions with positive migration balances ${ }^{32}$.

Several studies are focusing on land-use change in depopulated areas ${ }^{13,14,22,23}$, but no studies are focusing on landscape changes and trajectories. Consequently, the main goal of this study is to fill this research gap by analysing landscape changes in depopulated areas and areas with preserved populations.

This research builds on the results of a study conducted in rural areas of higher altitudes in $2017^{33}$. The comparative study carried out in 2017 at higher altitudes of Czechia indicated large differences in the overgrowth of agricultural land by forests in the depopulated areas and in the areas that remained settled. Current paper adds information regarding the change trajectories of depopulated areas in more fertile lands at lower altitudes (landscapes of lowlands and highlands). The results of the study proved, that population displacement and landscape type are important factors affecting changes of agricultural landscapes. We conclude results of the study to show knowledge gap as the point to focus on within this manuscript.

The answers to questions below can serve as one of the bases in creating the concept of nature protection, landscape planning and subsidy policy in agriculture in the future.

The following research questions to be answered are:

- What changes and trajectories of agricultural land exist in lowlands and highlands? Answering this question will help us to determine the effect of the post-war population displacement on the landscape change in lowlands and highlands. Many mountain areas across Europe were depopulated in the second half of the twentieth century. In case of the Sudetenland, this depopulation was massive and fast, thus differences are expected and have not been described in detail yet in Czechia.

- How do the trajectories of agricultural land affected by population expulsion differ from the trajectories of those which remained inhabited? Our study focuses on agricultural land, which is a landscape component that is directly dependent on human management. A long-term change in population is always reflected in agricultural land changes. In extreme cases, there is a reversal of large-scale forest vegetation development. On the other hand, extensively farmed mosaic landscapes of a high biological value can develop. Therefore, the question above should also be answered, to reveal variety of change

- What is the effect of depopulation on the landscape microstructure? Changes of spatial configuration of agricultural land patches have not yet been described although shape and area of patches can play substatial role for landscape functioning. Thus, quantification of these changes can bring useful insights for landscape management.

\section{Data and methods}

Study area. Selection of study sites. This study included ten sites in the region of Northern Bohemia in Czechia (Fig. 1). These sites serve as good examples of areas that were depopulated after the Second World War as well as areas that were only marginally affected by this sudden drop in population. The study sites are located in the area where the boundaries between depopulated and undepolupatedregion form an elevation gradient. Therefore it is possible to compare areas with different demographic developments at different altitudes. This setting is relatively rare in Czechia.

Study site areas. Each of the ten rectangular study sites cover 1800 ha. Five of them represent depopulated areas, and the other five sites area where populations remained preserved. 

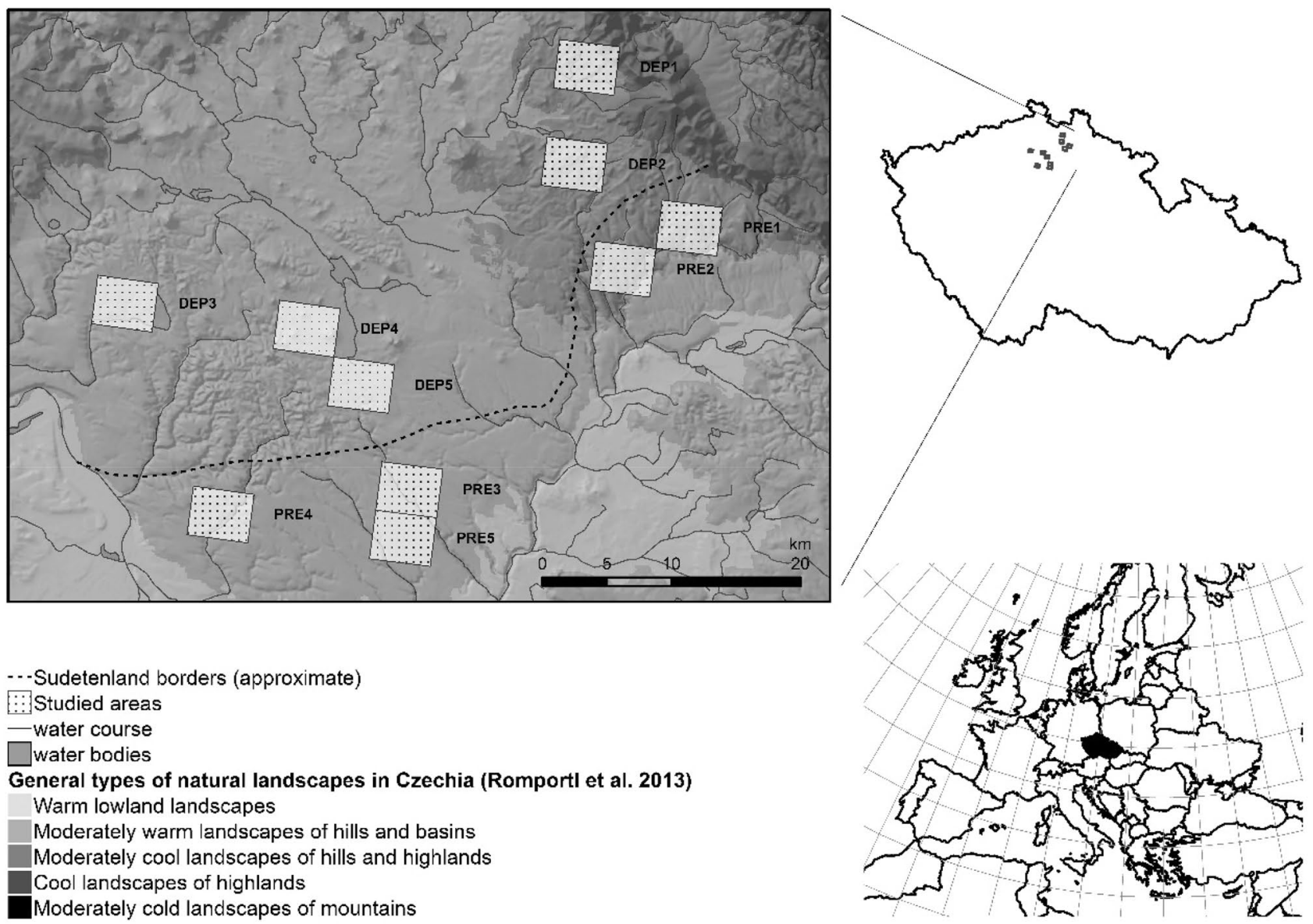

Figure 1. Location of the study sites in Northern Bohemia in Czechia. Study sites in the depopulated region are labelled DEP1-DEP5, sites in the region with preserved population are labelled PRE1-PRE5 (map created in the ArcGIS 10.6 software $^{34}$ ).

Demographic characteristics. As a demographic dataset for this study, we used census data from 1 December $1930^{35}$. Based on the census demographic information, territories, where more than $80 \%$ of the population was made up by individuals of German nationality, were selected as depopulated areas. The areas with more than $80 \%$ of the Czechoslovak nationality population were chosen as preserved ones.

Landscape types. Landscape typology combines climatic and geomorphologic characteristics, such as average annual temperature, slope, and elevation; based on these factors, six general types of natural landscapes (hereinafter 'landscapes types') were defined by Romportl et al. ${ }^{30}$. Five study sites were chosen in each demographic area type (depopulated or preserved). Within each demographic grouping, three of the study sites were within the landscape type of moderately warm landscapes of hills and basins (hereinafter simply 'lowlands') and two in moderately cool landscapes of hills and highlands (hereinafter 'highlands') defined by Romportl et al. ${ }^{30}$. At least $80 \%$ of the area of each studied site belongs to the respective landscape type. The landscape types covered in this study are described in more detail below:

1. Lowlands Within this type of a natural landscape we studied six sites covering a total area of 10,800 ha (see Fig. 1) - three depopulated sites (a total of 5400 ha; study sites DEP3-DEP5 in Fig. 1) and three preserved sites (PRE3-PRE5 in Fig. 1).

2. Highlands We studied four highland sites with a total area of 7200 ha-two were depopulated sites (a total of 3600 ha; DEP1 and DEP2 in Fig. 1), and two were preserved sites (PRE1 and PRE2 in Fig. 1).

All of the studied sites are situated near the demarcated borderline of the area dominated by the German population and the area dominated by the Czechoslovak population before the Second World War ${ }^{28}$.

Data sources. The change trajectories were analysed using GIS to compare agricultural land cover in 1953, representing the state of the landscape shortly after the displacement of the Sudeten Germans, with the current 2018 time horizon. Historical and contemporary land cover information was provided by aerial photographic images from 1953 and aerial orthophotos from 2016 to 2017. Additional field mapping was also carried out on selected sites in summer 2018. 


\begin{tabular}{|l|l|}
\hline Land cover category & Comments \\
\hline Agricultural lands (AL) & The category aggregates arable land with meadows and pastures \\
\hline Non-forest woody vegetation (NF) & $\begin{array}{l}\text { Non-forest woody species vegetation in form of patches according to Demková and Lipský } \\
\text { Linear elements (for example, alleys, riparian vegetation, vegetation along roads and railways, on } \\
\text { balks etc.) are not taken into account }\end{array}$ \\
\hline Forest areas (FOR) & Forest areas of a various age and origin \\
\hline Water areas (WAT) & Water course and water bodies \\
\hline Orchards, gardens, urban green (OG) & Intensively or extensively cultivated orchards and gardens. Also coniferous tree nurseries \\
\hline Succession mixed cover (SUC) & Succession mixed cover of shrubs and herbaceous vegetation according to Raška et al. ${ }^{44}$ \\
\hline Rural roads (RR) & Unpaved rural and forest roads \\
\hline Roads and railroads (ROA) & Paved roads, railways and paved parking areas \\
\hline Built-up areas (BUI) & $\begin{array}{l}\text { Residential and non-residential built-up areas, farmsteads, technical equipment warehouses and } \\
\text { factories }\end{array}$ \\
\hline Other areas (OAR) & Sports and industrial areas, agricultural facilities, cemeteries, landfills, quarries and dumps \\
\hline
\end{tabular}

Table 1. Land cover classification categories with codes used in change trajectories visualization.

Post-war time horizon (1953) and present time horizon (2018). For the purposes of this study, the post-war time horizon is represented by black and white aerial orthorectified images from $1953^{36}$. The period defined by these two aerial photographs (1953 and 2018) represents a very dynamic period in the development of the landscape throughout Europe. By 1953, the movement of the German population had ended in the Sudetenland ${ }^{28}$. These black and white images reflect the landscape structure condition before the subsequent collectivisation of agriculture during the socialist régime in Czechoslovakia, which had its own large impacts at the landscape level ${ }^{37,38}$ and also at the level of single habitats sensitive to specific management ${ }^{39}$. During this period, double-tracked or multi-tracked development of the landscape also started. It means that some more distant and less fertile areas were abandoned, while agriculture intensified in more fertile areas ${ }^{18}$. This phenomenon can be observed from the second half of the twentieth century throughout Europe. In the conditions of the Czechia, later transition from a socialist planning economy to a market economy has worsened the process. In the displaced areas, however, the black and white images make it impossible to distinguish farmland from grasslands and arable land, because many fields have been transformed into a wasteland due to a lack of population. Nonetheless, these photos still generally capture the structure of the landscape during the pre-war period. For the current land cover determination (2018), we used aerial full colour orthorectified pictures from 2016 to $2017^{40}$. We carried out additional field mapping in August 2018.

Data processing and analysis. Based on the aerial photograph data from 2016 to 2017 and the 1950s, vectorisation of polygons of selected land cover types was performed in the ArcGIS 10.6 software $^{34}$. For vectorisation over those raster data, we used backward interpretation ${ }^{41}$. By using this method, overlay analyses do not produce sliver polygons, which are not real changes in the landscape ${ }^{41}$, and require further repairs and processing $^{42}$. For purposes of this study, a special land cover category key was used. We distinguished ten types of land cover (see Table 1). As this study focuses on agricultural land, vectorisation was not performed in the entire studied territory, but only in areas with agricultural land present in 2018 or 1953. Similar approaches were taken in other studies such as Forejt et al..$^{39}$, Demková and Lipský ${ }^{38}$, and Zelinka ${ }^{33}$. A spatiotemporal analysis of changes was performed in ArcGIS 10.6 using the overlay analysis tool Itersect ${ }^{34}$. The agricultural land patches were then sorted into three persistence categories, reflectingd their change trajectories and spatiotemporal changes, according to Skaloš et al. ${ }^{43}$.

Persistence categories. Changes in the landscape were assessed through an analysis of the land use change, which, using GIS tools, identifies different persistence categories of landscape segments of agricultural land. Detailed information on spatiotemporal changes in the landscape was then obtained by identifying the so-called change trajectories of the landscape patches. Following three categories are distinguished:

- Continuous (present both in 1953 and 2018).

- Extinct (present in 1953 but transformed into a different category of land cover by 2018).

- Recent (created by 2018 from a different category of land cover).

For vector data of both time horizons, the area of each polygon and land cover category was calculated using ArcGIS $10.6^{34}$.

Monitored land cover categories. See Table 1.

Data computation and statistical analysis. Analysis of the change and developmental of change trajectories. A model based on the Poisson distribution and a contingency table was used to assess differences of agricultural land patch numbers (various types of persistence), with respect to their location within two different landscape types (lowlands-LOW/highlands-HIGH) and regions of different demographic history (depopu- 


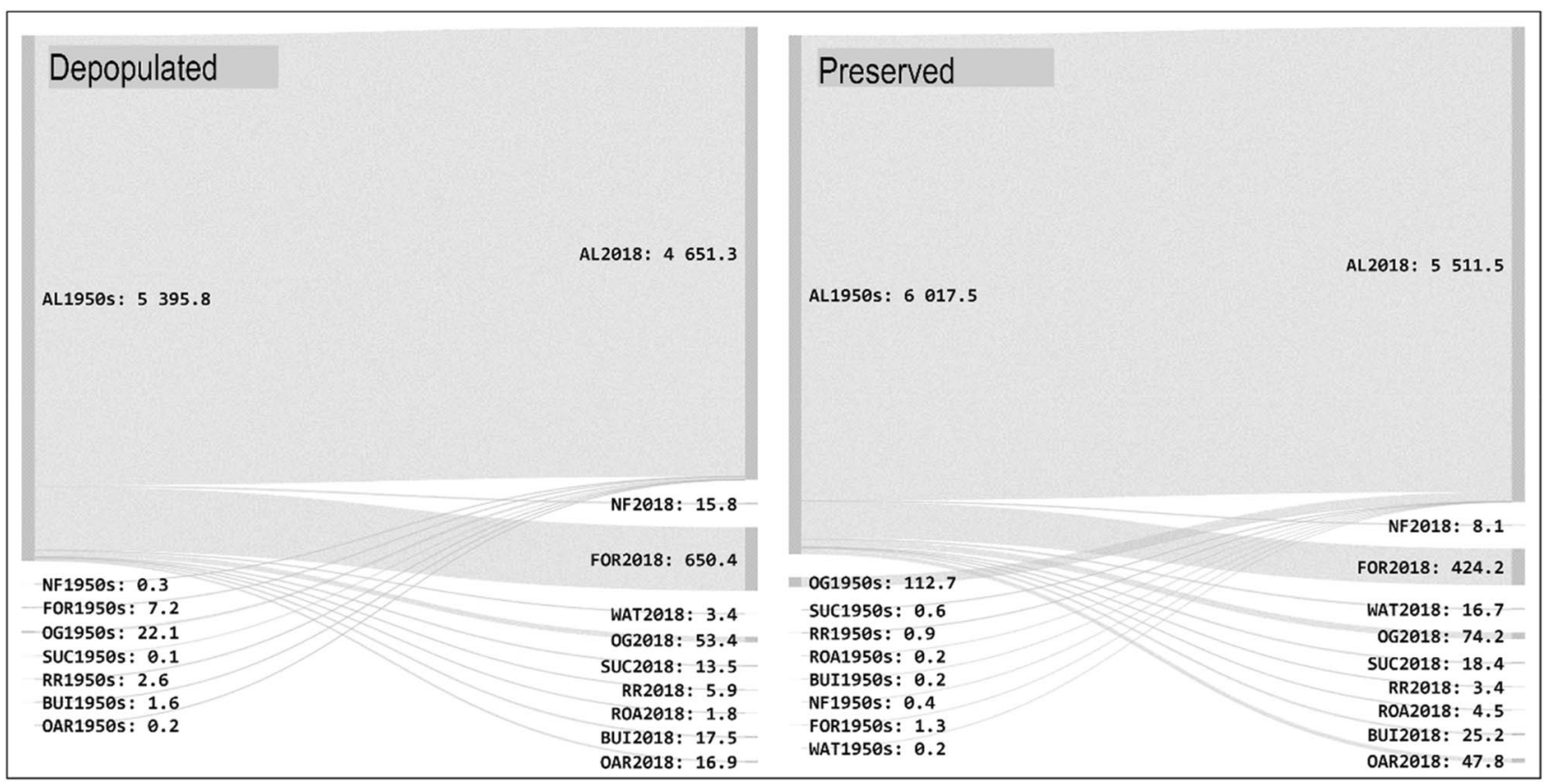

Figure 2. Overall change of agricultural land-change in trajectories between 1953 and the recent time horizon (in hectares). For land cover category codes see Table 1.

lated-DEP/preserved population-PRE). The effects of demography and landscape type were assessed by the share of particular persistence categories in study sites (after arcsin transformation of area $\mathrm{A}$ and shape index $\mathrm{Si}$ ). To assess the overall level of dynamics related to the study sites, an index of agricultural land (AL) change was calculated as the ratio of the share of extinct AL to total AL.

Concerning landscape microstructure analysis. Linear models and analysis of variance (ANOVA) were used to assess the variability of the area $(\mathrm{A})$ and the shape complexity of the patches ( $\mathrm{SI}=$ shape index). Both of these values were derived from vector datasets $\left(\mathrm{SI}=\right.$ Perimeter $/ \sqrt{ } \pi^{\star}$ Area $)$. The values of the area and shape index were log-transformed for analysis. Patch numbers of this AL trajectory in the context of different landscape type and demography history were assessed by chi-square tests using a contingency table. Area and shape complexity was assessed in detail for agricultural land regrown by forest (trajectory paths of AL_FOR) using an ANOVA.

\section{Results}

Overall change. Change in the use of agricultural land in the studied sites between 1953 and 2018 was relatively high both in depopulated areas and in areas with preserved populations. In depopulated areas (DEP1DEP5), there was a decrease in agricultural land from 5395.8 to 4651.3 ha during this period. This represents a decrease of approximately $14 \%$. The mean share of continuous agricultural land was $51.3 \%$ of depopulated study areas. Meanwhile in the preserved population study sites (PRE1-PRE5), agricultural land area also decreased by approximately $8.4 \%$ from 6017.5 ha in 1953 to 5511.5 ha in 2018 . Of these, 5394.9 ha fall within continuous areas. The agricultural land persistence for sites studied in depopulated areas and areas with preserved population is shown in Table 3. The agricultural land use is regarded as spatio-temporally stable.

As mentioned above, agricultural lands mapped in study sites in 2018 consist of both continuous (present in 1953 and 2018) and recent areas (created by 2018 in place of a different category of land cover). The share of recent agricultural land in the area of current (2018) agricultural land is $0.7 \%$ (34.1 ha) for depopulated areas and $2 \%(116.6 \mathrm{ha})$ in areas with preserved populations. The change trajectories of agricultural land in various persistence categories are shown in Sankey diagrams (Figs. 2 and 3). These diagrams show that the newly created agricultural land (recent) for both depopulated areas and areas with preserved population is predominantly made up of former orchards adjacent to settlements. The largest area of orchards converted into agricultural land between 1953 and 2018 is located in the Spikaly municipality within a region with preserved population, covering an area of 87.3 ha (study area PRE3; see Fig. 4). An exception is a relatively large area (5.4 ha) of agricultural reclamation of formerly forested areas in pits 6 and 7 of the Hamr II uranium mine, established in the 1980s (located in study area DEP2; see Fig. 4).

For depopulated areas, extinct patches of agricultural land make up a total of 778.6 ha and 622.5 ha for the areas with preserved population. The predominant type of change is the trajectory of agricultural land-forest (Fig. 2). This type of trajectory accounts for $84 \%$ of extinct agricultural land in depopulated areas and $68 \%$ in areas with preserved population.

Effect of landscape type and demographic character on the persistence of agricultural land. The results of the model glm ( $\sim$ persistence category ${ }^{*}$ demographic characteristics ${ }^{\star}$ landscape 


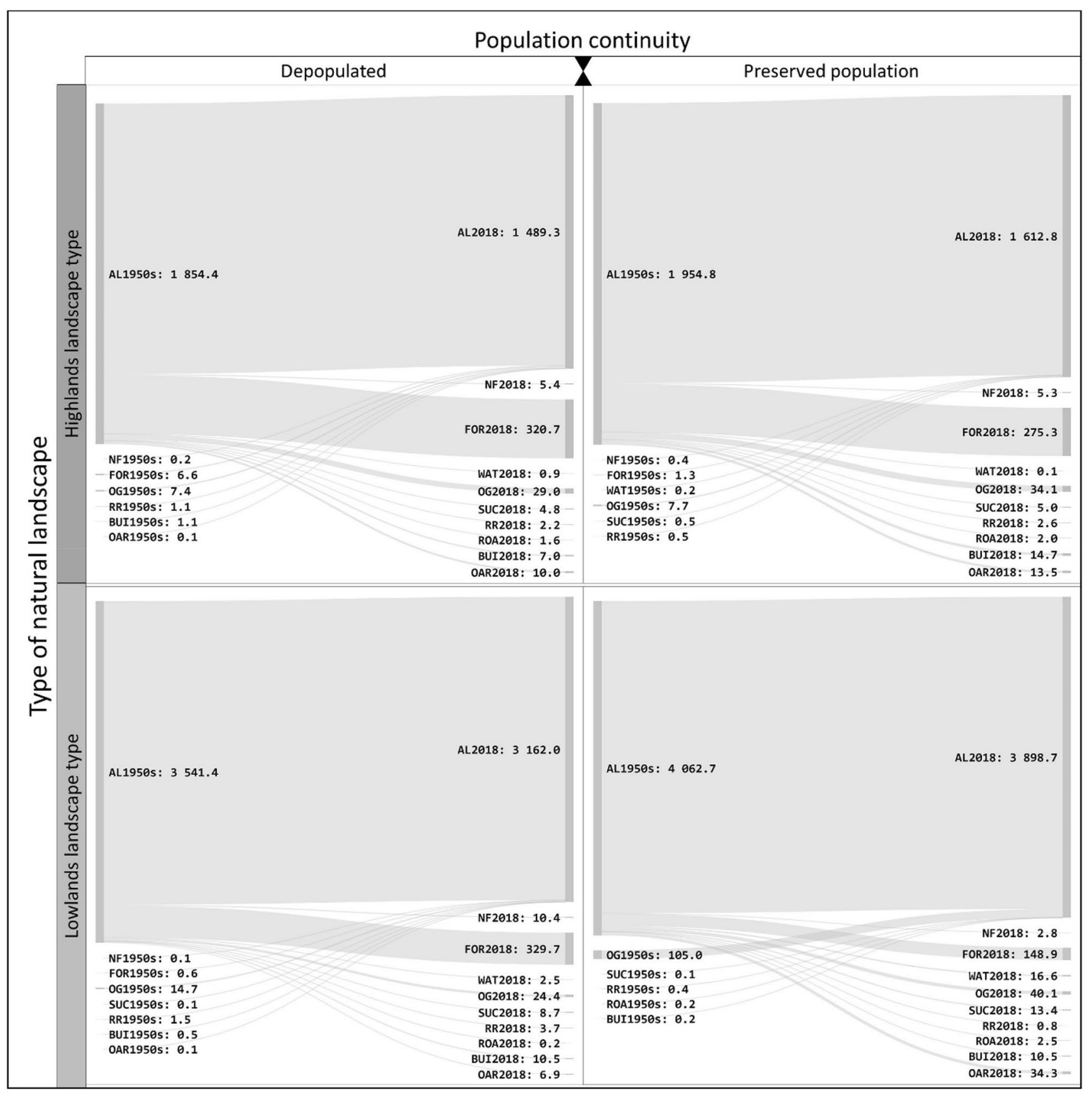

Figure 3. Agricultural land change trajectories between 1953 and the most recent time horizon in depopulated areas and in areas with preserved population considering their location in different landscape types (in hectares).

type, family = Poisson) suggest that the mean numbers of AL patches in categories of persistence (see Table 2 and Fig. 5) REC and EXT are significantly different from those in the continuous (CON) category $(p=0.01$, $p<2^{*} 10^{-16}$, respectively). Similarly, the mean numbers of AL patches between the Sudetenland and regions with preserved population, and between the two considered landscape types differ as well (both $p<2^{\star} 10^{-16}$ ).

Areas of particular persistence categories of agricultural land (continuous, extinct, and recent) in all of the study sites in depopulated areas and those with preserved population are shown in Table 3. For the spatial distribution of particular persistence categories within the study areas, see Fig. 4.

The effects of demography and landscape types were assessed by the share of particular persistence categories in study sites (after the arcsin transformation of $A$ ). The shares of patches of different persistence categories differ significantly among study sites for the continuous and extinct categories within landscape types (aov(arscin(\%continuous) demographic characteristics + landscape type: $\mathrm{df}=1, \mathrm{~F}=9.489, p=0.0178$; $\operatorname{aov}(\arcsin (\%$ extinct $) \sim$ demographic characteristics + landscape type: $\mathrm{df}=1, \mathrm{~F}=19.424, p=0.00313)$, but not by 


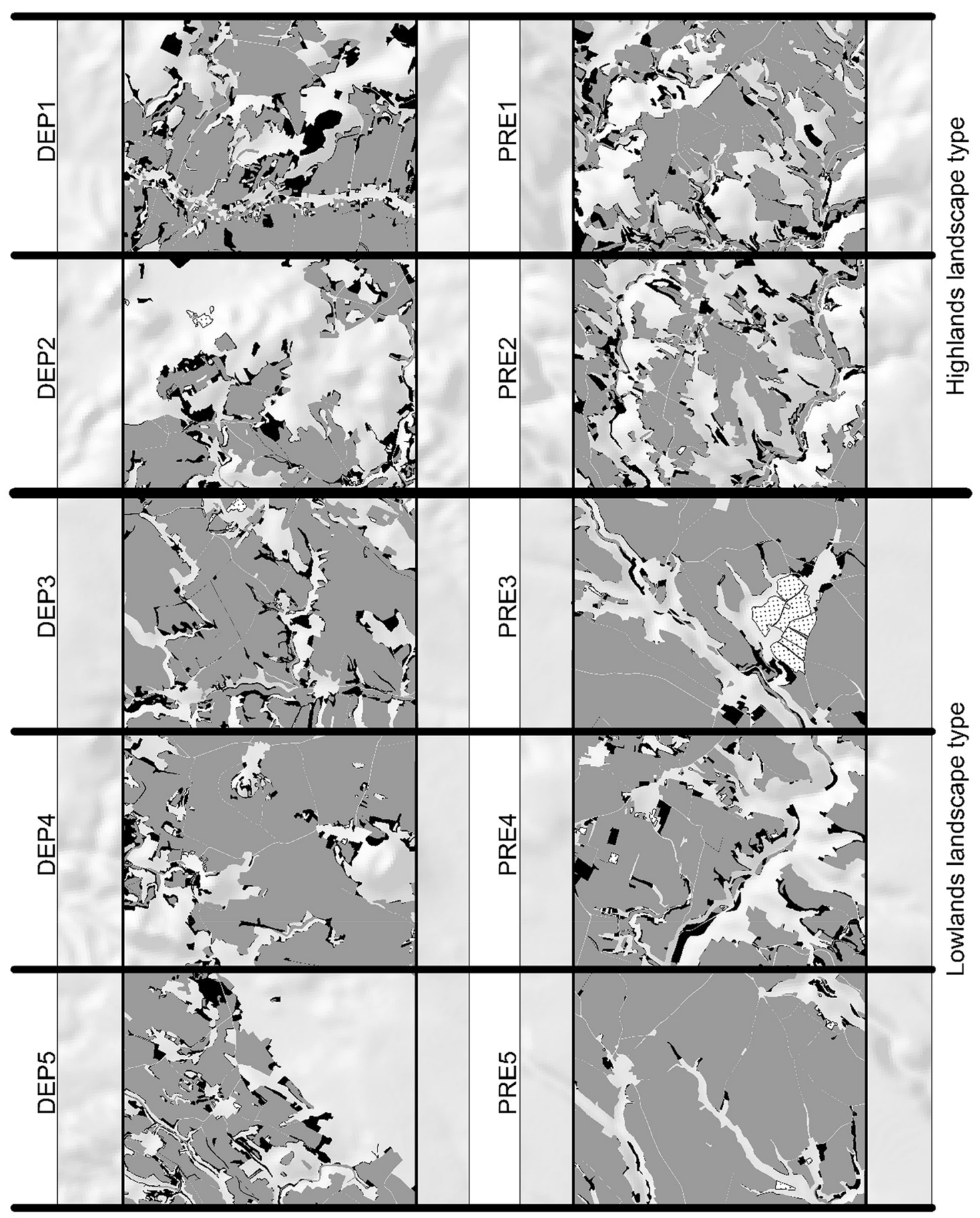

Agricultural land category

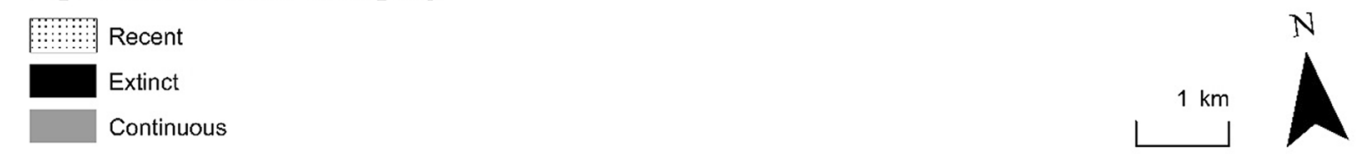

Figure 4. Spatial distribution of agricultural land persistence categories within the studied sites (maps created in the ArcGIS 10.6 software ${ }^{34}$ ). 


\begin{tabular}{|l|l|l|}
\hline & DEP & PRE \\
\hline CON & \multicolumn{2}{|l|}{} \\
\hline LOW & 382 & 384 \\
\hline HIGH & 174 & 494 \\
\hline EXT & \multicolumn{2}{|l|}{} \\
\hline LOW & 635 & 566 \\
\hline HIGH & 564 & 770 \\
\hline REC & \multicolumn{2}{|l}{} \\
\hline LOW & 110 & 59 \\
\hline HIGH & 129 & 95 \\
\hline
\end{tabular}

Table 2. Mean numbers of AL patches in individual categories of persistence.

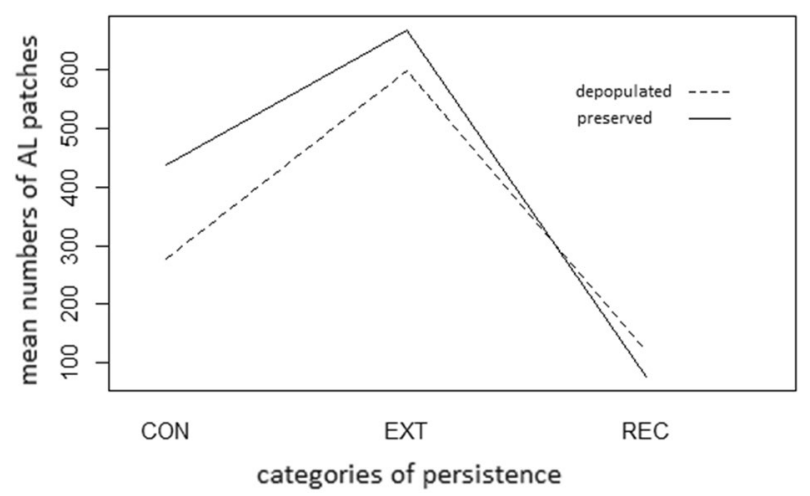

Figure 5. Mean numbers of AL patches in individual categories of persistence.

\begin{tabular}{|c|c|c|c|c|c|}
\hline & \multirow[b]{3}{*}{ ID } & \multirow{3}{*}{$\begin{array}{l}\text { Agricultural land in } 1953 \\
\text { \% Study area }\end{array}$} & \multicolumn{2}{|c|}{ Agricultural land in 2018} & \multirow{2}{*}{\begin{tabular}{|l|} 
Agricultural land losses 1953-2018 \\
Extinct \\
\end{tabular}} \\
\hline & & & Continuous & Recent & \\
\hline & & & \% Study area & \% Study area & \% Study area \\
\hline \multirow{5}{*}{ Depopulated } & DEP1 & 65.7 & 53.3 & 0.4 & 12.4 \\
\hline & DEP2 & 37.3 & 28.5 & 0.5 & 8.8 \\
\hline & DEP3 & 77.7 & 69.5 & 0.5 & 8.2 \\
\hline & DEP4 & 73.4 & 66.9 & 0.2 & 6.5 \\
\hline & DEP5 & 45.7 & 38.3 & 0.2 & 7.4 \\
\hline \multirow{5}{*}{ Preserved population } & PRE1 & 60.0 & 49.7 & 0.2 & 10.3 \\
\hline & PRE2 & 48.6 & 39.4 & 0.4 & 9.3 \\
\hline & PRE3 & 73.6 & 69.1 & 5.0 & 4.5 \\
\hline & PRE4 & 66.6 & 58.4 & 0.6 & 8.2 \\
\hline & PRE5 & 85.5 & 83.2 & 0.3 & 2.2 \\
\hline
\end{tabular}

Table 3. Agricultural land persistence for depopulated areas (DEP1-DEP5) and areas with preserved population (PRE1-PRE5).

the category recent. According to the model results, different demographic histories do not affect the share of persistence categories within study sites $(p<0.05)$.

To assess the overall level of dynamics related to the study sites, an index of AL change was calculated as the ratio of extinct AL share to total AL share. The level of dynamics in depopulated regions compared to regions with preserved population are higher based on Fig. 6. From Fig. 6 it is also evident that the mean index of change is higher in highlands and lower in lowlands.

Landscape microstructure analysis. Based on the model, $\log (\mathrm{A}) \sim$ persistence category + demographic characteristics + landscape type, it can be concluded that all the variables affect the aerial extent of AL patches (persistence category, demographic characteristics, landscape type; $\mathrm{df}=2, \mathrm{~F}=14.353, p=6.13^{\star} 10^{-7}$ ). The mean 


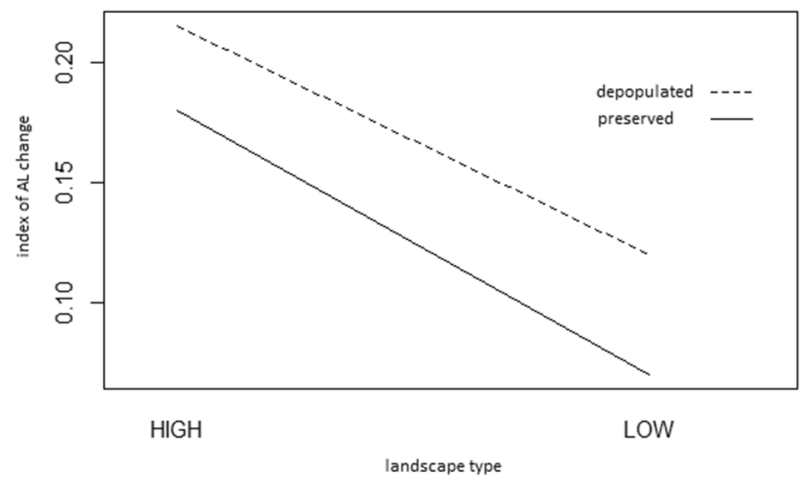

Figure 6. The level of dynamics in depopulated regions compared to regions with preserved population.

\begin{tabular}{|l|l|l|l|}
\hline Mean A in ha & CON & EXT & REC \\
\hline DEP_HIGH & 8.46 & 0.68 & 0.13 \\
\hline DEP_LOW & 8.23 & 0.63 & 0.16 \\
\hline PRE_HIGH & 3.24 & 0.46 & 0.11 \\
\hline PRE_LOW & 9.90 & 0.48 & 1.80 \\
\hline
\end{tabular}

Table 4. Mean area of patches among persistence categories.

\begin{tabular}{|l|l|l|}
\hline & DEP & PRE \\
\hline HIGH & 4.106532 & 4.014099 \\
\hline LOW & 4.280266 & 3.646679 \\
\hline
\end{tabular}

Table 5. Shape complexity in respect to the position of patches within regions of different.

\begin{tabular}{|l|l|l|l|}
\hline MeanSI & CON & EXT & REC \\
\hline DEP_HIGH & 3.58 & 4.28 & 4.07 \\
\hline DEP_LOW & 3.46 & 4.79 & 4.22 \\
\hline PRE_HIGH & 3.31 & 4.43 & 4.33 \\
\hline PRE_LOW & 3.07 & 4.06 & 3.44 \\
\hline
\end{tabular}

Table 6. Mean shape index of patches of different persistence categories of AL.

area of patches among persistence categories differ within landscape types $\left(\mathrm{df}=2, \mathrm{~F}=1253.5, p<0.2^{\star} 10^{-16}\right)$, and also between former regions of the Sudetenland and Protektorát $(\mathrm{df}=2, \mathrm{~F}=7.914, p=0.0004)$ (see Table 4).

Concerning the shape complexity with respect to the position of patches within regions of different demographic history in combination with two landscape types (aov $\left(\log (\mathrm{SI}) \sim \operatorname{landscape}\right.$ type ${ }^{*}$ demographic characteristics), we can conclude that the shape indices in the Sudetenland and outside of it differ significantly in lowlands $(p=0)$ but not in highlands $(p=0.82)$. We can also observe that the shape of AL varies significantly between landscape types in regions with preserved population $\left(p=10^{-8}\right)$ but not within the former Sudetenland region $(p=0.07)$ (see Table 5).

The results of the model $\log (\mathrm{SI}) \sim$ persistence category ${ }^{\star}$ demographic characteristics ${ }^{\star}$ landscape type, focused on the assessment of patch shape complexity, can be summarised in the following way: the mean patch shape indices of AL differ significantly among persistence categories $\left(\mathrm{df}=2, \mathrm{~F}=190.635, p=2^{\star} 10^{-16}\right)$ as well as among regions with different demographic histories $\left(\mathrm{df}=1, \mathrm{~F}=27.789 ; p=1.42^{\star} 10^{-7}\right)$. At the same time, we conclude that the mean shape index of patches of different persistence categories differ significantly in context with landscape type $(\mathrm{d}=2, \mathrm{~F}=4.785, p=0.00862)$ and also mean shape index of patches from depopulated regions and those with preserved population within the context of two landscape types $\left(\mathrm{d}=1, \mathrm{~F}=44.464, p=2.91^{\star} 10^{-11}\right)$ (see Table 6$)$.

Overgrowth by woody vegetation as a typical way of agricultural land perishing in the Sudetenland. Patch numbers of this AL change trajectory within the context of different landscape types and 


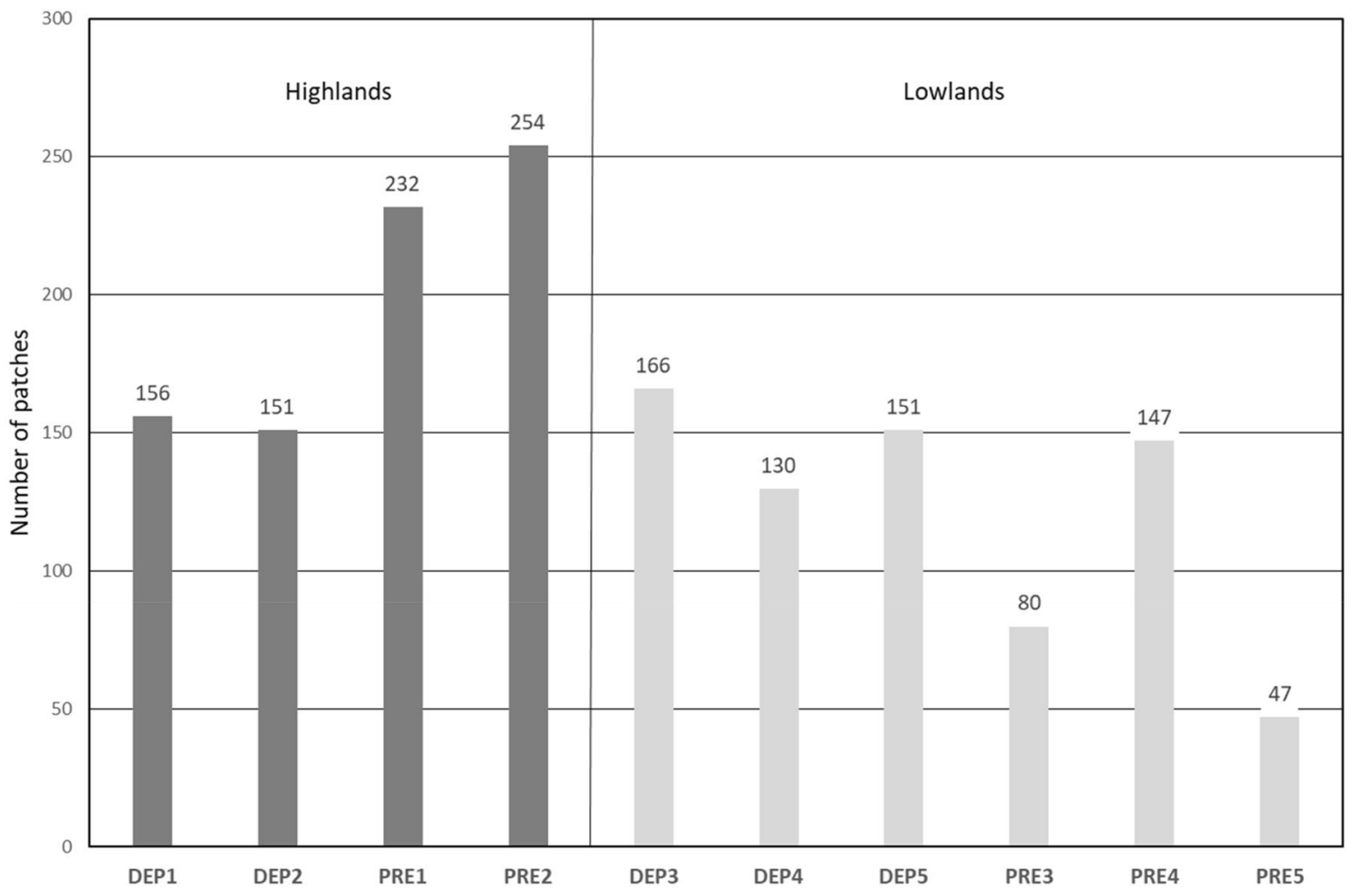

Figure 7. Number of patches with change trajectories of agricultural land-forest and agricultural land-nonforest woody vegetation in the depopulated and non-depopulated areas.

\begin{tabular}{|l|l|l|l|l|l|l|l|l|l|l|}
\hline Study site & DEP1 & DEP2 & DEP3 & DEP4 & DEP5 & PRE1 & PRE2 & PRE3 & PRE4 & PRE5 \\
\hline Mean A (ha) & 1.14 & 0.94 & 0.70 & 0.79 & 0.73 & 0.59 & 0.55 & 0.40 & 0.62 & 0.55 \\
\hline Mean SI & 4.44 & 4.38 & 4.76 & 4.60 & 5.04 & 4.61 & 4.37 & 5.12 & 4.34 & 4.32 \\
\hline
\end{tabular}

Table 7. Mean area and shape index of the patches with the trajectories of agricultural land-forest and agricultural land-non-forest woody vegetation in the depopulated and non-depopulated areas.

demographic histories were assessed using the chi-square test and contingency table. Test results show that both the landscape types and demographic characters of the regions affect the numbers of patches of this trajectory $(p=0.05)$, for details see Fig. 7 .

Area and shape complexity was assessed in detail for agricultural land overgrown by forest (trajectory paths of $A L_{-}$ FOR) by using ANOVA. The results of models aov $(\log (\mathrm{A})$ demographic characteristics + landscape type) and aov $\left(\log (\mathrm{SI}) \sim\right.$ demographic characteristics ${ }^{\star}$ landscape type) show that the area and shape index of patches of $A L$ regrown by forest are significantly affected by their location within or outside of the Sudetenland (area: $\mathrm{df}=1$, $\mathrm{F}=5.972, p=0.146$; shape index: $\mathrm{df}=1, \mathrm{~F}=5.969, p=0.147$ ), but not by landscape type. For details see Table 7 .

When looking at the areas of extinct agricultural land with the trajectory of Agricultural land-forest in depopulated and preserved areas, a certain visual difference is often obvious in the internal structure of the newly emerging forest. While the most common cause of this in depopulated areas is probably is the expansion of the forest to the detriment of earlier agricultural land by spontaneous succession, in preserved areas it is often controlled forestation (Fig. 8).

\section{Discussion}

Discussion on results. It is clear from the results of our analysis that declines in the area of agricultural lands occurred in depopulated areas as compared to the non-depopulated areas, particularly given to increases in the area of woody vegetation due to the extensification of agriculture as a result of population displacement ${ }^{28}$. Changes in land use from the 1950s to the present are thus corroborated in the studied depopulated and preserved areas mainly by the trajectory of agricultural land-forest. Similar studies showed this trend is discernible across Europe $e^{13,22,32,45}$ and corresponds with the known principles of cultural landscape dynamism ${ }^{20,46}$. The causes of abandonment of land differ. For the most part, long-term declines in population tied to migration to the urban areas and more fertile areas is perceptible ${ }^{12}$. However, this study concerns depopulated areas, where the gradual abandonment of the area is overshadowed by a rapid and mass decline in the population due to the forced displacement of the Germans after the Second World War ${ }^{25,28}$. When we compare the trajectory of extinct 

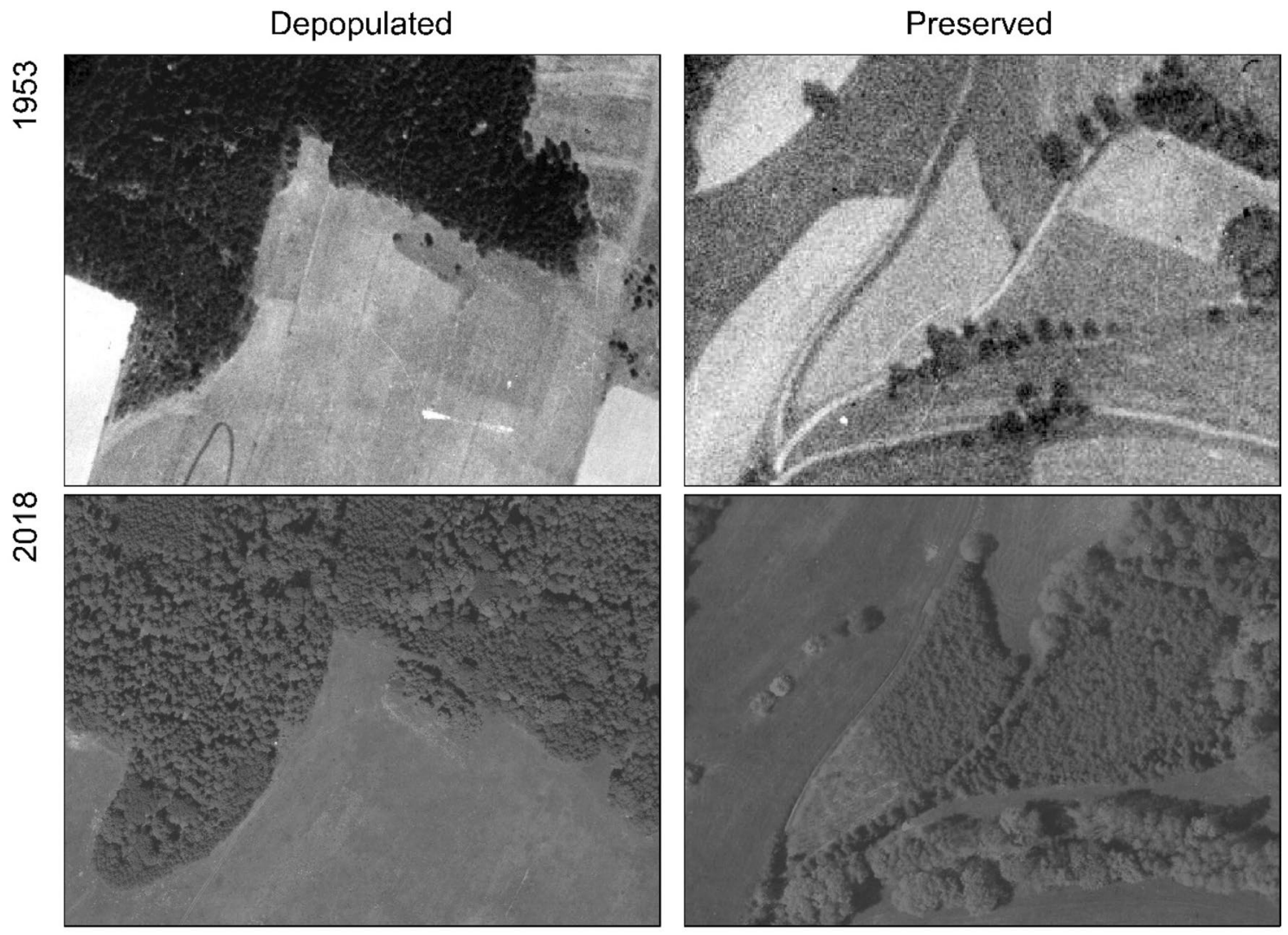

Figure 8. Noticeable visual difference in the dynamics of a new forest. Spontaneous succession and controlled afforestation (sources of aerial data: orthorectified images from $1953^{36}$, colour orthorectified images from 2016 to $2017^{40}$,maps generated in the ArcGIS 10.6 software $^{34}$.

agricultural land in depopulated and preserved areas, the difference in the intensity of forest ingrowth in favour of depopulated areas is clear from the diagrams (Figs. 2 and 3). Similarly, this also applies to the comparison of the landscape types in a given area where the depopulated and preserved areas fall under the highlands landscape type, which manifest a substantially higher percentage of agricultural land transformed into forest land. The statistical processing performed here confirms that the average size of new forest patches is probably influenced by an area's location in depopulated or preserved regions. In depopulated areas, the average size of the new forest patches to the detriment of agricultural land is larger as compared to non-depopulated areas, and the general sizes of new forest patches in depopulated areas are larger than in non-depopulated areas.

If we ignore these specific development trajectories and focus on the persistence of agricultural land, the difference between the depopulated and non-depopulated areas is less obvious. According to the linear model results, the size of agricultural land areas in various persistence categories exhibit a statistically significant difference between the lowlands and highlands landscape types. Also, location within depopulated or preserved areas does play a role according to the model results. Differences in the size of agricultural land areas between the lowlands and highlands landscape types may be because the character of the cultural landscape is a function of the environment. It is influenced by long-term geomorphological conditions in the form of the settlement of living organisms and disturbances ${ }^{20}$. The combination of these factors makes the character of settlement and mode of landscape management ${ }^{47}$, and thus also the shape of the agricultural areas, conditional. In this context, even the fact that the share of areas of persistence in the continuous and extinct categories in the total area of the model significantly differs between the landscape types is no surprise. Again, this can be easily explained by the different (generally smaller scale) agricultural use of the landscape in the highlands ${ }^{48}$. The shape index derived from vector datasets $\left(\mathrm{SI}=\right.$ Perimeter $/ \sqrt{ } \pi^{\star}$ Area) of agricultural land regrown by forest (trajectory paths of AL_FOR) is influenced by the demography.

Based on comparisons of the quality of the models $\left(\mathrm{AIC}_{\text {DEMOGRAPHY }}=3572.3<\mathrm{AIC}_{\text {LANDSCAPE TYPE }}=3548.0\right.$ ), the shapes of landscape segments are to a large extent affected by their location in depopulated or in preserved areas rather than to the landscape type. This confirms the general principles of landscape ecology, where the main factor influencing the contrast in the landscape (and partly also the nature of the boundaries of landscape segments) is man (cultural landscape-high contrast, natural landscape-low contrast) ${ }^{20}$. For this reason, the influence of settlement is more significant in this case than the type of natural landscape. It is also obvious from the analysis that the extinct (EXT) and recent (REC) areas are, in terms of shape statistics, significantly different from the continuous areas $(\alpha=0.05)$. This may be partly influenced by the results of the GIS analysis, which, to some extent, affect the shape of the landscape segments. On the other hand, this may be influenced by the 
different character and functioning of landscape segments given by the fact that they originated differently and have a different character in the landscape (continuous, recent).

Discussions on methodology. It should be noted that the demographic divisions of the study territory do not exactly match the borders of the areas occupied by Nazi Germany in 1938. The main reason is that the German military occupation did not adhere to the boundaries of individual cadastral areas ${ }^{49}$. Thus, even part of the cadastral areas with a larger share of the Czech population also fell under the occupied territory. This created a string of small disputed areas along the border of the Sudetenland. However, our study sites are far enough away from this indefinite boundary.

Our study sites were chosen from a broader area, where the boundary between the depopulated and nondepopulated areas have transects across the belts of the landscape types proposed by Romportl et al. ${ }^{30}$. Thus, the landscape types used as the geographical framework of the study drew from both the lowlands and the highlands. This fact provides a unique opportunity to compare the responses of the landscape to the sudden depopulation in the transect from the most fertile areas of the lowlands to less fertile mountainous areas ${ }^{50}$. However, it is necessary to mention the fact that some of the study sites (DEP2 and DEP5) fall partially under the large stable forest areas (approximately $400 \mathrm{~km}^{2}$ ). Here, the typical matrix of the Czech agricultural landscape of the lowlands changes from a forest enclave in an agricultural landscape to enclaves of agricultural areas in the forest. These areas are characterised by poor soils, extremely sparse networks of watercourses, and other conditions ${ }^{51,52}$, and thus, are significantly different from the rest of the lowlands landscape type in which they fall. These are sparsely populated areas that correspond to colonisation failures in the Middle Ages ${ }^{53}$ and areas that were used long-term by the Soviet Army. In terms of accompanying facilities, infrastructure, and recultivation, these areas are also afflicted by the large-scale chemical mining of uranium ore from the 1960s to the 1980s. It is thus necessary to ask the questions of whether these two study sites can even be fully considered agricultural landscapes and to what extent these circumstances can influence the results of the analyses. As already stated in the results, DEP2 has a relatively large area of new agricultural land ( $5.4 \mathrm{ha}$ ) that results from the agricultural reclamation of formerly forested areas of pits 6 and 7 from the Hamr II uranium mine established in the 1980s. Information about this agricultural land, which became extinct in connection with the mining and military use of the area and is not related to the initial expulsion of the population, is difficult to corroborate. The use of aerial photographs from multiple periods and mapping of land use in the period before the post-war expulsion of population ${ }^{54}$ would, to a certain extent, contribute to the acquisition of such data.

The land cover categories used in this study were chosen with regard to the focus of the study ${ }^{55}$. This concerns the typical landscape cover of agricultural landscape types 2 through 5 as defined by Romportl et al. ${ }^{30}$. However, the use of this key seems to be problematic in some areas of the Sudetenland which, due to the local natural conditions, have a larger share of natural grasslands (e.g., dry grasslands) that freely build on the agricultural landscape. In these areas, it is not possible to expect the same response to depopulation as seen in the rest of the grasslands in the agricultural landscape because they are probably not primarily determined by human management ${ }^{56}$. In the conditions of the Czechia, these areas occur in the hottest and driest areas of the country, particularly in Northern, Central, and Eastern Bohemian as well as in South Moravia ${ }^{57}$. In the Sudetenland area, only the areas in the Louny Highlands are under consideration.

Depopulation or displacement of the population, is an important factor of landscape changes, which affects several landscape features and their characteristics. However, in the history of the landscape, as well as in history in general, we will be significantly influenced by the availability and nature of the source materials used: 'we only see what the materials allow us. Here, too, we observe these changes on the changes of landscape elements, which are well recognisable on the used substrates, i.e., woody plants. Unfortunately, it is more difficult to interpret permanent grassland, where the change would be much more noticeable. From the point of view of the model, collectivization processes in agriculture in the second half of the twentieth century can also be problematic. It is of course not possible to determine that the collectivization process took place in the same way in all municipalities. However in terms of land ownership, the development of the two areas can be considered similar. Mainly due to their proximity to each other. Since 1946, when controlled settlement took place, land has been allocated to new settlers. From 1948, however, the pressure from Moscow to implement uncompromising collectivization intensified significantly. This subsequently led to the implementation of collectivization into a law. These legal norms have been strictly applied in the whole territory of the then Czechoslovakia since 1950.

\section{Conclusions}

A decrease in the area of agricultural land was recorded in both types of landscapes. However, the results of the study show that in the landscape where the population was displaced, there was an almost two-fold decrease in the area of agricultural land (from 14 to $8.4 \%$ ). There is also a higher proportion of continuous habitats of agricultural land in relation to the size of the landscape parts, where there was no displacement of the population $(60 \%$ versus 51.3\%). A larger decrease in the area of agricultural land, a higher proportion of disappeared agricultural land enclaves, and a smaller proportion of continuous agricultural land habitats prove that population density and consequent displacement are significant factors of landscape changes that lead to extensification of land use. This is reflected in a reduction in the distribution of agricultural land and its greater spatiotemporal changes. If the areas of agricultural land disappear, it most often occurs in favour of forests and in the landscape affected by the displacement of the population (in $84 \%$ of the cases). This trend is also very common in a country unaffected by depopulation, but in a smaller number of cases $(68 \%)$.

Landscape type has a statistically significant effect on the representation of continuous and extinct areas of agricultural land, but not on recent areas of agricultural land. On the other hand, the effect of displacement has 
not been proven. If changes are assessed by the index of changes, the magnitude of this change is higher in the landscape affected by displacement, and also in higher altitudes.

The results show that both factors (landscape type and the displacement of the population) significantly affect the number and average size of the areas. The average number of areas of new and extinct agricultural land categories is significantly different from the continuous agricultural land. The average number of patches of individual persistence categories of both displaced/not displaced and highlands/lowlands also differs statistically. Both the type of landscape and the displacement of the population statistically significantly affect the number of areas and their average size, i.e., they are strong factors that affect landscape management and thus the basic characteristics of landscape microstructure, which is influenced by landscape management.

In contrast to the landscape type, the shape of the patches is significantly affected by the displacement of the population in the lowland landscape. In a landscape unaffected by population displacement, the landscape type has a significant effect on the shape of the patches. The shape of the patches differs significantly in the individual development categories of patches of agricultural land, as well as between the landscape affected and unaffected by the displacement of the population. The shape of the patches also differs between individual landscape types and between landscapes affected and unaffected by population displacement.

The results prove that both population displacement and landscape type are important factors that affect landscape changes, especially agricultural landscapes. This is manifested on the one hand by a change in the area, the representation of individual developmental elements of agricultural land, and also by the basic characteristics of the landscape microstructure. Interestingly, we found that this effect is not as 'strong' and differs between the characteristics of the change within the landscape type.

Received: 14 December 2020; Accepted: 31 May 2021

Published online: 16 June 2021

\section{References}

1. Haddaway, N. R., Styles, D. \& Pullin, A. S. Environmental impacts of farm land abandonment in high altitude/mountain regions: A systematic map of the evidence. Environ. Evid. 2(1), 18. https://doi.org/10.1186/2047-2382-2-18 (2013).

2. Bender, O., Boehmer, H. J., Jens, D. \& Schumacher, K. P. Analysis of land-use change in a sector of Upper Franconia (Bavaria, Germany) since 1850 using land register records. Landsc. Ecol. 20(2), 149-163. https://doi.org/10.1007/s10980-003-1506-7 (2005).

3. Biró, M., Szitár, K., Horváth, F., Bagi, I. \& Molnár, Z. Detection of long-term landscape changes and trajectories in a Pannonian sand region: Comparing land-cover and habitat-based approaches at two spatial scales. Community Ecol. 14(2), 219-230. https:// doi.org/10.1556/ComEc.14.2013.2.12 (2013).

4. Schulp, C. J. E., Levers, C., Kuemmerle, T., Tieskens, K. F. \& Verburg, P. H. Mapping and modelling past and future land use change in Europe's cultural landscapes. Land Use Policy 80, 332-344. https://doi.org/10.1016/j.landusepol.2018.04.030 (2019).

5. González Díaz, J. A., Celaya, R., Fernández García, R., Osoro, K. \& Rosa García, R. Dynamics of rural landscapes in marginal areas of northern Spain: Past, present, and future. Land Degrad. Dev. 30, 141-150. https://doi.org/10.1002/ldr.3201 (2018).

6. Hersperger, A. M., Gennaio, M.-P., Verburg, P. H., \& Buergi, M. Linking land change with driving forces and actors: Four conceptual models. Ecol. Soci. 15(4) (2010). Retrieved from http://apps.webofknowledge.com.infozdroje.czu.cz/full_record.do?product=UA\& search_mode=GeneralSearch\&qid=1\&SID=R1PQ9zBCVnF6m2Wcyo8\&page $=1 \&$ doc $=2$.

7. Khromykh, V. \& Khromykh, O. Analysis of spatial structure and dynamics of Tom Valley landscapes based on GIS, digital elevation model and remote sensing. Proc. Soc. Behav. Sci. 120, 811-815. https://doi.org/10.1016/j.sbspro.2014.02.165 (2014).

8. Kienast, F. Analysis of historic landscape patterns with a geographical information system? A methodological outline. Landsc. Ecol. 8(2), 103-118. https://doi.org/10.1007/BF00141590 (1993).

9. Matsushita, B., Xu, M. \& Fukushima, T. Characterizing the changes in landscape structure in the Lake Kasumigaura Basin, Japan using a high-quality GIS dataset. Landsc. Urban Plan. 78(3), 241-250. https://doi.org/10.1016/j.landurbplan.2005.08.003 (2006).

10. Plieninger, T. et al. Patterns and drivers of scattered tree loss in agricultural landscapes: Orchard meadows in Germany (1968-2009). PLoS ONE https://doi.org/10.1371/journal.pone.0126178 (2015).

11. Swetnam, R. D. Rural land use in England and Wales between 1930 and 1998: Mapping trajectories of change with a high resolution spatio-temporal dataset. Landsc. Urban Plan. 81(1-2), 91-103. https://doi.org/10.1016/j.landurbplan.2006.10.013 (2007).

12. Eurostat. Life in Cities. Urban Europe-Statistics on Cities, Towns and Suburbs. (Publications Office of the European Union, 2016). https://doi.org/10.2785/91120

13. Fernández Ales, R. Effect of economic development on landscape structure and function in the Province of Seville (SW Spain) and its consequences on conservation. In Land Abandonment and Its Role in Conservation, Options Mediterraneennes, Serie A, Seminaires Mediterraneens Vol. 15 (eds Baudry, J. \& Bunce, R. G. H.) 61-69 (Options Méditerranéennes, 1991).

14. Falcucci, A., Maiorano, L. \& Boitana, L. Changes in land-use/land-cover patterns in Italy and their implications for biodiversity conservation. Landsc. Ecol. 22, 617-631 (2007).

15. Antrop, M. Why landscapes of the past are important for the future. Landsc. Urban Plan. https://doi.org/10.1016/j.landurbplan. 2003.10.002 (2004).

16. Janečková Molnárová, K., Skřivanová, Z., Kalivoda, O. \& Sklenička, P. Rural identity and landscape aesthetics in exurbia: Some issues to resolve from a Central European perspective. Morav. Geogr. Rep. 25(1), 2-12. https://doi.org/10.1515/mgr-2017-0001 (2017).

17. Bičík, I., Jeleček, L. \& Štěpánek, V. Land-use changes and their social driving forces in Czechia in the 19th and 20th centuries. Land Use Policy 18(1), 65-73. https://doi.org/10.1016/S0264-8377(00)00047-8 (2001).

18. Lipsky, Z. The changing face of the Czech rural landscape. Landsc. Urban Plan. 31(1-3), 39-45. https://doi.org/10.1016/01692046(94)01034-6 (1995).

19. Prishchepov, A. V., Radeloff, C. V., Baumann, M., Kemmerle, T. \& Müller, D. Effects of institutional changes on land use: Agricultural land abandonment during the transition from state-command to market-driven economies in post-Soviet Eastern Europe. Enivron. Res. Lett. 7, 024021. https://doi.org/10.1088/1748-9326/7/2/024021 (2012).

20. Forman, T. T. R. \& Godron, M. Landscape Ecology (Wiley, 1986).

21. Míchal, I. Ekologická Stabilita (Veronica, 1994).

22. Bucala, A. The impact of human activities on land use and land cover changes and environmental processes in the Gorce Mountains (Western Polish Carpathians) in the past 50 years. J. Environ. Manag. 138, 4-14 (2014).

23. Kozak, J. Forest cover change in the western Carpathians in the past 180 years. A case study in the Orawa region in Poland. $M t$. Res. Dev. 23(4), 369-375 (2003).

24. Latocha, A. Land-use changes and longer-term human-environment interactions in a mountain region (Sudetes Mountains, Poland). Geomorphology 108(1), 48-57. https://doi.org/10.1016/j.geomorph.2008.02.019 (2009). 
25. Prauser, S. \& Rees, A. The expulsion of the "German" communities from Eastern Europe at the end of the Second World War (Badia Fiesolana, 2004).

26. Petráš, R. Reforma správy a národní otázka na počátku první republiky. Historický Obzor: Časopis pro Výuku Dějepisu a Popularizaci Historie 13(5), 133-137 (2002).

27. Bičík, I. \& Kabrda, J. Land use changes in Czech border regions (1845-2000). AUC Geogr. 42, 23-52 (2007).

28. Staněk, T. \& von Arburg, A. Vysídlení Němců a proměny českého pohraničí 1945-1951 (I.) (Vysídlení) (Zdeněk Susa, 2010).

29. Weber, M. Dědictví krajiny jako výzva pro její současné obyvatele. In Proměny sudetské krajiny, Antikomple (ed. Spurnný, M.) (Nakladatelství Českého lesa, 2006).

30. Romportl, D., Chuman, T. \& Lipsky, Z. Landscape typology of Czechia. Geografie 118(1), 16-39 (2013).

31. Estel, S. et al. Mapping farmland abandonment and recultivation across Europe using MODIS NDVI time series. Remote Sens. Environ. 163, 312-325. https://doi.org/10.1016/J.RSE.2015.03.028 (2015).

32. Levers, C., Schneider, M., Prishchepov, A. V., Estel, S. \& Kuemmerle, T. Spatial variation in determinants of agricultural land abandonment in Europe. Sci. Total Environ. 644, 95-111. https://doi.org/10.1016/J.SCITOTENV.2018.06.326 (2018).

33. Zelinka, V. Continuity and extinction of agricultural land in the sudetes-A case study in the landscape of highlands and mountains. J. Landsc. Ecol. 11(2), 53-66. https://doi.org/10.2478/jlecol-2018-0006 (2018).

34. ESRI. ArcGIS 10.6 (2017).

35. Statistický lexikon obcí v republice Československé. (I). (Ministerstvo vnitra a Státní úřad statistický.Orbis, 1934).

36. CENIA. Historické letecké snímky-50. léta. https://www.cenia.cz (2012).

37. Bičík, I. et al. Land use changes in the Czech republic 1845-2010 (Springer, 2015).

38. Demková, K. \& Lipský, Z. Změny nelesní dřevinné vegetace v jihozápadní části bílých karpat v letech 1949-2011. Geogr. Sb. CGS 120(1), 64-83 (2015).

39. Forejt, M., Skalos, J., Pereponova, A., Plieninger, T. \& Vojta, J. Changes and continuity of wood-pastures in the lowland landscape in Czechia. Appl. Geogr. 79, 235-244. https://doi.org/10.1016/j.apgeog.2016.12.016 (2017).

40. ČÚZK. Geoportál ČÚZK-př́stup k mapovým produktům a službám resortu. https://geoportal.cuzk.cz/ (2016).

41. Skokanová, H. Application of methodological principles for assessment of land use changes trajectories and processes in Southeastern Moravia for the period 1836-2006 Eastern Moravia for the period 1836-2006. Acta Pruhon. 91, 15-21 (2015).

42. Grossmann, E. B. \& Mladenoff, D. J. Open woodland and savanna decline in a mixed-disturbance landscape (1938 to 1998) in the Northwest Wisconsin (USA) Sand Plain. Landsc. Ecol. 22, 43-55 (2007).

43. Skaloš, J. et al. What are the transitions of woodlands at the landscape level? Change trajectories of forest, non-forest and reclamation woody vegetation elements in a mining landscape in North-western Czech Republic. Appl. Geogr. 58, 206-216. https://doi. org/10.1016/j.apgeog.2015.02.003 (2015).

44. Raška, P., Zábranský, V., Brázdil, R. \& Lamková, J. The late Little Ice Age landslide calamity in North Bohemia: Triggers, impacts and post-landslide development reconstructed from documentary data (case study of the Kozí vrch Hill landslide). Geomorphology 255, 95-107. https://doi.org/10.1016/j.geomorph.2015.12.009 (2016).

45. Amici, V. et al. Anthropogenic drivers of plant diversity: Perspective on land use change in a dynamic cultural landscape. Biodivers. Conserv. 24(13), 3185-3199. https://doi.org/10.1007/s10531-015-0949-x (2015).

46. Bürgi, M. et al. Processes and driving forces in changing cultural landscapes across Europe. Landsc. Ecol. 32(11), 2097-2112. https://doi.org/10.1007/s10980-017-0513-z (2017).

47. Raška, P., Hruška, V. \& Kolektiv, A. Adaptabilita a Resilience (Univerzita J.E. Purkyně v Ústí nad Labem, 2014).

48. CENIA. CORINE Land Cover 2012 Databáze České Republiky (2014).

49. Juřena, J. Soumrak nad českým Podkrkonoším: Německá opkuace Novopacka a Jilemnicka v roce 1938. (FORTprint, 2013).

50. Czech Geological Survey. Soil Map of Czech Republic (2018).

51. Meduna, P. \& Sádlo, J. Bezdězsko-Dokesko. Krajina mezi odolností a stagnací. Hist. Geogr. 35(1), 147-160 (2009).

52. Novák, J., Sádlo, J. \& Svobodová-svitavská, H. Unusual vegetation stability in a lowland pine forest area (Doksy region, Czech Republic). Holocene 22(8), 947-955. https://doi.org/10.1177/0959683611434219 (2012).

53. Klápště, J. Proměna českých zemí ve středověku. (Lidové noviny, 2012).

54. Engstová, B. \& Petř́čck, V. Landscape and vegetation in a military area-Past and present. J. Landsc. Stud. 1, 91-102 (2008).

55. Turner, M. G. \& Gardner, R. H. Landscape Ecology in Theory and Practice 2nd edn. (Springer, 2015).

56. Chytrý, M. (ed.) Vegetace České republiky 1. Travinná a keř́ćčková vegetace (Academia, 2007).

57. Chytrý, M., Kučera, T., Kočí, M., Grulich, V. \& Lustyk, P. Katalog biotopů České republiky (Agentura ochrany př́rody a krajiny ČR, 2010).

\section{Acknowledgements}

The project was supported by the Czech University of Life Sciences, Faculty of Environmental Sciences, project IGA FZP No. 20164227 Development of the Sudetes landscape-change trajectories, immediate causes and main driving forces.

\section{Author contributions}

All mentioned authors contributed equally to this study.

\section{Competing interests}

The authors declare no competing interests.

\section{Additional information}

Correspondence and requests for materials should be addressed to V.Z.

Reprints and permissions information is available at www.nature.com/reprints.

Publisher's note Springer Nature remains neutral with regard to jurisdictional claims in published maps and institutional affiliations. 
(c) (i) Open Access This article is licensed under a Creative Commons Attribution 4.0 International cc) License, which permits use, sharing, adaptation, distribution and reproduction in any medium or format, as long as you give appropriate credit to the original author(s) and the source, provide a link to the Creative Commons licence, and indicate if changes were made. The images or other third party material in this article are included in the article's Creative Commons licence, unless indicated otherwise in a credit line to the material. If material is not included in the article's Creative Commons licence and your intended use is not permitted by statutory regulation or exceeds the permitted use, you will need to obtain permission directly from the copyright holder. To view a copy of this licence, visit http://creativecommons.org/licenses/by/4.0/.

(C) The Author(s) 2021 